\title{
Fibroblast Growth Factor Gene Family
}

National Cancer Institute

\section{Source}

National Cancer Institute. Fibroblast Growth Factor Gene Family. NCI Thesaurus. Code C18568.

The Fibroblast Growth Factor Gene Family encodes Fibroblast Growth Factor peptides, potent mitogens that stimulate mesodermal cell growth, including chondrocytes, granulosa, and endothelia, and may be active in wound healing and regeneration. $(\mathrm{NCl})$ 